\title{
OBRAZ ROSJI, BIAŁORUSI I UKRAINY W JĘZYKOWEJ ŚWIADOMOŚCI POLSKICH STUDENTÓW FILOLOGÓW (WYNIKI EKSPERYMENTU LINGWISTYCZNEGO) ${ }^{1}$
}

\author{
MARZANNA KAROLCZUK \\ Uniwersytet $w$ Białymstoku \\ m.karolczuk@uwb.edu.pl \\ ORCID: 0000-0003-3457-4910
}

\section{STRESZCZENIE}

Umiejętność właściwego porozumiewania się z przedstawicielami innych kultur jest kluczowym atutem we współczesnym zglobalizowanym świecie. Jej jakość uzależniona jest od znajomości języka obcego oraz wiedzy, jaką posiada jednostka o współrozmówcy. W celu pozyskania informacji na temat wyobrażeń funkcjonujących $\mathrm{w}$ świadomości polskich studentów na temat kultury rosyjskiej, białoruskiej i ukraińskiej, która odzwierciedla ich wiedzę i może być przesłanką do przygotowania ich do kontaktów interkulturowych, przeprowadzono eksperyment lingwistyczny. W badaniu zastosowano wśród 24 studentów filologii rosyjskiej test asocjacyjny i zebrano 555 polskojęzycznych swobodnych reakcji na zawarte $\mathrm{w}$ ankiecie bodźce dotyczące Rosji, Białorusi i Ukrainy. Wyniki eksperymentu lingwistycznego pokazały, że generalnie obraz trzech kultur jest stereotypowy. Jednak wiedza respondentów o Rosji i Rosjanach pozyskiwana $\mathrm{w}$ ramach kilkuletniego kształcenia akademickiego jest obszerniejsza niż o Białorusi i Białorusinach oraz Ukrainie i Ukraińcach. Wyniki badania pokazały również, że przygotowanie do kontaktów interkulturowych i zwiększenie szansy młodych ludzi na rynku pracy wymaga wprowadzenia zmian w programach akademickich.

SŁOWA KLUCZOWE: porozumiewanie się interkulturowe; skojarzenia; stereotypy; kultura rosyjska, ukraińska i białoruska; filologia rosyjska.

\section{IMAGE OF RUSSIA, BELARUS AND UKRAINE IN THE LANGUAGE AWARENESS OF POLISH PHILOLOGY STUDENTS (RESULTS OF THE LINGUISTIC EXPERIMENT)}

\section{ABSTRACT}

The ability to properly communicate with representatives of other cultures is a key asset in the modern globalized world. Its quality depends on the knowledge of a foreign language and the knowledge one has about their co-interlocutor. In order to obtain information on the ideas functioning in the minds of Polish students about the Russian, Belarusian and Ukrainian culture, which reflects their knowledge and can be a premise to prepare them for intercultural contacts, a linguistic experiment has been conducted. The study used an association test among 24 students of Russian philology: 555 free Polish-language responses to stimuli about Russia, Belarus and Ukraine were collected. The results of the linguistic experiment have shown that, in general, the image of the three cultures is stereotypical. However, the respondents' knowledge of Russia and Russians, acquired as part of several years of academic education, is more extensive than that of Belarus and Belarusians as well as Ukraine and Ukrainians. The results of

\footnotetext{
1 Projekt finansowany w ramach programu Ministra Nauki i Szkolnictwa Wyższego pod nazwą „Regionalna Inicjatywa Doskonałości” na lata 2019-2022 nr projektu 09/RID/2018/19 kwota finansowania $8791222,00 \mathrm{zł}$.
} 
the study also showed that preparing for intercultural contacts and increasing the chances of young people on the labour market requires changes in academic curricula.

KEYWORDS: intercultural communication; associations; stereotypes; Russian, Ukrainian and Belarusian culture; Russian philology.

\section{WPROWADZENIE}

Satysfakcjonujące porozumiewanie się z przedstawicielami innej kultury niż nasza w obszarze relacji tak zawodowych, jak i prywatnych jest umiejętnością złożoną i trudną do opanowania. Jednocześnie jest uznawana za kluczową kompetencję XXI wieku.

Wyniki przeprowadzonych dotychczas badań pokazuja, że słabe umiejętności interkulturowe jednostek znacząco wpływają na efektywność porozumiewania się ludzi reprezentujących różne kultury i zaniżają jakość kontaktów (Miller 2000; Malau-Aduli, Ross, Adu 2019; Suzuki, Ando, Nishikawa 2019; Takhtarova, Abuzyarova, Kuzmina 2019; Zhang, Zhou 2019). Dotyczy to różnorodnych sytuacji życiowych, począwszy od towarzyskich, poprzez edukacyjne i kończąc na zawodowych. Jak ważna jest to umiejętność świadczą również prace nad nowoczesnymi technologiami tłumaczenia językowego z obsługą mowy uwzględniające komunikację interkulturowa, które składają się z systemów rozpoznawania mowy na tekst i systemów komputerowego tłumaczenia oraz badania naukowe weryfikujące ich skuteczność (Shadiev, Sun, Huang 2019).

Celem artykułu jest prezentacja wyników z badania empirycznego na temat utrwalonego $\mathrm{w}$ świadomości polskich studentów filologii rosyjskiej obrazu Rosji, Białorusi i Ukrainy oraz refleksji o poziomie przygotowania młodych Polaków do interkulturowych dialogowych interakcji.

\section{OD WIEDZY DO POROZUMIEWANIA SIĘ INTERKULTUROWEGO}

Porozumiewanie się interkulturowe $\mathrm{w}$ kontekście poniższych rozważań dotyczy kontaktu jednostek reprezentujących różne kultury i mówiących $\mathrm{w}$ języku, który przynajmniej dla jednego z rozmówców jest językiem obcym, nie drugim. Proces ten, rozumiany jako skuteczna interakcja i dialog, zależy od wielu czynników, w tym od znajomości znaków werbalnych oraz od poziomu rozwoju kompetencji interkulturowej (Białek 2009; Grabowska, Kania 2014; Karolczuk 2016; Biebricher, East, Howard, Tolosa 2019; Zhang, Zhou 2019).

Jak podkreśla się w literaturze,

chodzi nie tylko o wzajemne zrozumienie na poziomie słów, zdań, dłuższych wypowiedzi, a nawet na poziomie języka niewerbalnego, ale o zrozumienie lokujące się $\mathrm{w}$ obszarze kulturowym. Jest to możliwe, jeśli współrozmówcy są świadomi tego, że reprezentują inne grupy językowo-kulturowe i akceptują te różnice. (Karolczuk 2016: 75) 
Warto pamiętać, że nawet najprostszy proces porozumiewania się ma złożoną strukturę i zawsze - nawet wówczas, gdy nie uświadamiamy sobie tego- kreują się „dwa wzajemnie przenikające się wymiary: pierwszy kognitywny, odnoszący się do przekazywanych znaczeń i informacji, drugi, relacyjny, polegający na budowaniu więzi interpersonalnych" (Lubecka 2010: 17).

Wspomniana wyżej kompetencja interkulturowa jest pojęciem interpretowanym wielokierunkowo, ale jej rozwój ma prowadzić do wspólnego celu - ułatwienia funkcjonowania w świecie wielu kultur, skutecznego porozumiewania się $\mathrm{w}$ duchu dialogu, akceptacji innych i lepszego zrozumienia siebie oraz swojej społeczności kulturowej (Zawadzka 2004, Jelizarowa 2005, Wilczyńska 2005, Galskowa 2008). Można również zauważyć, że dla lepszego zrozumienia tego terminu zostały wyodrębnione jego elementy, to jest postawy, wiedza i umiejętności (Byram 1997, Sadochin 2007, Apalkow 2011). Jelizarowa (2005) podkreśla, iż kompetencja interkulturowa, której podstawą jest wiedza i umiejętności, pomaga realizować interkulturowe porozumiewanie się i ostatecznie osiągnąć pozytywny dla obu partnerów końcowy rezultat. Zaznacza ona jednak, że kompetencja ta nie jest tożsama z komunikacyjną kompetencją osoby, dla której dany język jest językiem pierwszym, i że może dotyczyć wyłącznie mediatora kultur uczącego się języka obcego.

Wiedza, jako komponent kompetencji interkulturowej, obejmuje wielostronne informacje na temat świata, kultury własnej i kraju, z którego pochodzi współrozmówca w szerokim kontekście historycznym, geograficznym i społecznym. Jest to wiedza o kulturze materialnej i duchownej danej grupy językowo-kulturowej, o społeczeństwie i warunkach jego funkcjonowania. Dotyczy ona takich obszarów, jak realioznawstwo, krajoznawstwo, socjoznawstwo oraz kulturoznawstwo sensu stricto (Pfeiffer 2001). Wielu badaczy zwraca uwagę, że to właśnie wiedza - rzetelna, nie połowiczna- jest podstawowym kluczem w kształtowaniu kompetencji interkulturowej (Myczko 2002; Wilczyńska 2002; Magala 2011; KornackaSkwara, Skwara 2010; Mihułka 2012).

Postawy odnoszą się do percepcji emocjonalnych i intelektualnych jednostki, czyli takich zjawisk, jak empatia, otwartość, ciekawość, unikanie etnocentryzmu w kontekście własnej kultury, stereotypy, uprzedzenia, czy zaufanie do zachowań przedstawicieli innej kultury (Byram 1997).

W literaturze przedmiotu podkreśla się, że ilość i jakość wiedzy rzutuje na kształtowanie postaw i możliwość ich modyfikacji (Myczko 2002, Wilczyńska 2002, Mihułka 2012). Deficyt informacji o przedstawicielach innych kultur, z którymi jednostka wchodzi w relacje, wpływa na początkowe wyobrażenie o nich i można określić je jako stereotypowe. Często są to też uprzedzenia wobec innych ludzi. Stereotypy, określone przez Lippmanna (1997) „trwałymi obrazami w głowie", powstają w wyniku pobieżnego i niestarannego procesu 
poznawczego (Błuszkowski 2003: 24). Nie są efektem bezpośrednich kontaktów z określonymi grupami językowo-kulturowymi, pojawiają się przed spotkaniem z nimi (zob. Adebayo 2019). Im więcej mamy wiedzy (rzetelnej lub zniekształconej) na temat jakiegoś obiektu, tym mniej dana postawa podatna jest na zmiany. Częstotliwość łączenia danego obiektu z oceną oraz sposób pozyskania takiej konotacji i emocjonalnego nastawienia wpływa na trwałość postaw ukształtowanych na bazie uczuć. Należy zaznaczyć, że również nieświadome skojarzenia wpływają na ocenę danego obiektu (Mihułka 2015).

Umiejętności postrzegane jako wypadkowa wiedzy i postaw odnoszą się do praktycznego ich wykorzystania w kontaktach bezpośrednich i za pomoca technologii informacyjno-komunikacyjnych oraz w kontaktach pośrednich poprzez wytwory kultury wysokiej (Mihułka 2012). Ta płaszczyzna zorientowana na działanie dotyczy takich zdolności, jak: 1) obserwowanie i interpretowanie dokumentów i wydarzeń odnoszących się do kultury własnej i obcej; 2) rozpoznawanie podobieństw i różnic w ramach tych kultur; 3) nabywanie nowej wiedzy o kulturze; 4) obiektywnej oceny poglądów, wartości, zachowań w zakresie kultury swojej i obcej (Byram 1997).

Wiedza, postawy i umiejętności nie mogą prawidłowo funkcjonować bez wzajemnego powiązania, oddziaływania na siebie. Nabycie kompetencji interkulturowej $\mathrm{w}$ procesie edukacji językowej jest uwarunkowane rozwojem wszystkich trzech jej części. W konsekwencji rozwija się umiejętność efektywnego i satysfakcjonujące porozumiewania się interkulturowego w sferze prywatnej, edukacyjnej i zawodowej.

Prowadzenie badań diagnostycznych dotyczących omawianego tu obszaru, a następnie wdrażanie odpowiednich rozwiązań edukacyjnych jest ważne, ponieważ od tego

w jaki sposób członkowie danej grupy społecznej myślą i wypowiadają się w jej imieniu i na jej rzecz, oraz od tego, co poszczególne grupy etniczne wzajemnie na swój temat sądzą, jakie stereotypy wzajemnie tworza, zależy zarówno motywacja do podejmowania jakichkolwiek kontaktów, jak i przebiegu procesu komunikacji. (Gawarkiewicz 2012: 111)

\section{Metodologia}

W czerwcu 2019 przeprowadzono wśród 24 studentów II roku studiów magisterskich eksperyment lingwistyczny, którego celem była diagnoza i analiza treści wyobrażeń istniejących w świadomości polskich studentów filologii rosyjskiej na temat szeroko rozumianej kultury rosyjskiej, białoruskiej i ukraińskiej.

Badanie miało odpowiedzieć na pytania:

1) Jaka jest wiedza studentów na temat społeczności, z którymi mogliby oni realizować swoje potrzeby zawodowe, porozumiewając się $\mathrm{w}$ języku rosyjskim? 
2) Jakie asocjacje (pozytywne, negatywne, neutralne) na temat państw sąsiadujących z Polską dominują w świadomości młodych ludzi?

3) Czy studenci filologii rosyjskiej są przygotowani do porozumiewania się interkulturowego z przedstawicielami innych kultur?

$\mathrm{W}$ badaniu zastosowano test asocjacyjny ${ }^{2} \mathrm{~W}$ ramach którego studenci mieli zapisać pierwsze skojarzenia na zaprezentowane przez badacza bodźce (1. Pierwsza część ankiety: Rosja, Rosjanie, kultura rosyjska, gospodarka rosyjska, rosyjska polityka wewnętrzna, rosyjska polityka zagraniczna; 2. Druga część ankiety: Białoruś, Białorusini, kultura białoruska, gospodarka białoruska, białoruska polityka wewnętrzna, białoruska polityka zagraniczna; 3. Trzecia część ankiety: Ukraina, Ukraińcy, kultura ukraińska, gospodarka ukraińska, ukraińska polityka wewnętrzna, ukraińska polityka zagraniczna). ${ }^{3} \mathrm{~W}$ wyniku eksperymentu asocjacyjnego zebrano materiał językowy w postaci 555 polskojęzycznych swobodnych werbalnych reakcji na zawarte $\mathrm{w}$ ankiecie bodźce.

Ankietowani respondenci są szczególną grupą z dwóch powodów. Po pierwsze, dlatego, że są studentami filologii rosyjskiej, którzy w czerwcu kończyli 2-letnie studia magisterskie. Wszyscy oni ukończyli także filologię rosyjską na poziomie 3-letnich studiów licencjackich. Reasumując, respondenci studiowali język rosyjski i poznawali kulturę rosyjską przez pięć lat. Wszyscy ankietowani są świadomi, że język rosyjski jest środkiem komunikacji, za pomocą którego można porozumiewać się $\mathrm{z}$ różnymi społecznościami, szczególnie bloku wschodniego, w tym z Rosjanami, Białorusinami i Ukraińcami, tak w kraju, jak i za granicą oraz na terenie państw, które można określić jako turystyczne. Po drugie, badana grupa w zdecydowanej większości mieszka na terenie województwa podlaskiego, które jest szczególnie często odwiedzane przez turystów rosyjskojęzycznych oraz na terenie którego, jak i poza jego granicami, rozwija się handel między polskimi i rosyjskojęzycznymi przedsiębiorcami.

\section{WYNIKI BADANIA}

W wyniku eksperymentu zebrany został materiał językowy w postaci 234 polskojęzycznych swobodnych werbalnych reakcji dotyczących Rosjan i Rosji, 145 - Białorusinów i Białorusi oraz 176- Ukraińców i Ukrainy na zawarte w ankiecie bodźce. Wyniki zostaną omówione zgodnie z kolejnością pytań zawartych w ankiecie. Zarejestrowane skojarzenia były bardzo zróżnicowane,

\footnotetext{
2 W eksperymencie wykorzystane zostało narzędzie diagnostyczne zastosowane przez Gawarkiewicza (2012: 116-126) do zbadania stereotypów i autostereotypów funkcjonujących w świadomości polskich, niemieckich i rosyjskich studentów.

3 Badanie jest większym projektem obejmującym wszystkie roczniki filologii rosyjskiej. Niniejszy artykuł ukazuje część wyników z przeprowadzonego eksperymentu.
} 
niejednokrotnie nie można było przyporządkować ich do większej grupy. Poniżej zostaną przedstawione najczęstsze asocjacje wskazane w badaniu.

\section{Pierwsza część ankiety - obszar rosyjski}

a) Rosja (21,37\% wszystkich asocjacji dotyczących obszaru rosyjskiego)

Respondenci najczęściej kojarzyli Rosję z pięknym i olbrzymim krajem (30\% reakcji językowych), pisząc m.in.: piękny kraj; ogromny kraj; największe państwo; ogromny obszar. Nazwy miejsc stanowiły 24\% skojarzeń. Były to: Kreml, Moskwa, Petersburg, Plac Czerwony, Syberia (Sybir). Asocjacje dotyczące typowych rosyjskich symboli religijnych (cerkwie), językowych (cyrylica), ludowych (matrioszka), przyrodniczych (niedźwiedź), kulinarnych (bliny) stanowiły $18 \%$ konotacji. Z Rosją kojarzony był również prezydent państwa Putin (8\%).

b) Rosjanie (18,80\% wszystkich asocjacji dotyczących obszaru rosyjskiego)

Studenci najczęściej (59,09\% skojarzeń werbalnych) Rosjan kojarzą z pozytywnymi cechami charakteru, osobowości. Respondenci użyli między innymi takich określeń mieszkańców Federacji Rosyjskiej, jak: gościnni; otwarci; patrioci; mili; pracowici; tolerancyjni; zwiazani z tradycja. W ankiecie pojawiły się też negatywne określenia (15,91\%), np.: nie stroniq od alkoholu; dużo pija; alkoholicy. Ankietowani zwracali uwage na wygląd zewnętrzny Rosjan (11,36\%), np.: piękne stroje; poważne miny; futra.

c) Kultura rosyjska (27,35\% wszystkich asocjacji dotyczących obszaru rosyjskiego)

W tym punkcie ankiety studenci najczęściej odwoływali się do kultury wysokiej oraz, nieco rzadziej - do popularnej (37,5\%), określając ją m.in. jako: wspaniałe dzieła architektury; bardzo bogata literatura; dużo pięknej muzyki oraz wymieniając konkretnych jej przedstawicieli (Achmatowa; Buthakow; Czechow; Lermontow; Szołochow; Puszkin; Szukszyn; Tołstoj). Respondenci zapisali również tytuł popularnej piosenki (Миллион альıх poз), baletu (Jezioro Łabędzie) oraz nazwę rosyjskiego akademickiego chóru męskiego (Chór Aleksandrowa). Kultura kojarzona jest również z różnorodnością dań (bliny; kapuśniak; zupa rybna) kuchni rosyjskiej $(10,94 \%)$, z symbolami sztuki ludowej (10,94\%) takimi, jak matrioszka czy samowar, a także religią prawosławną $(7,81 \%)$. W ankiecie zidentyfikowano taką samą ilość $(7,81 \%)$ słów charakteryzujących kulturę rosyjską (np. zróżnicowana; bogata, kolorowa), jak również odnoszących się wprost do folkloru, pięknych strojów narodowych.

\footnotetext{
${ }^{4}$ Kursywą zostały odnotowane odpowiedzi ankietowanych studentów, które odpowiadają oryginalnemu zapisowi.
} 
d) Gospodarka (13,25\% wszystkich asocjacji dotyczących obszaru rosyjskiego)

Gospodarka rosyjska kojarzona jest głównie (48,39\%) z surowcami energetycznymi (gaz ziemny; ropa naftowa; wegiel) oraz rozwojem (16,13\%). Jako asocjacje na bodziec 'gospodarka' studenci pisali między innymi: szybko się rozwija; bogactwo; bardzo rozwinięta.

e) Polityka wewnętrzna (8,55\% wszystkich asocjacji dotyczących obszaru rosyjskiego)

Zdecydowanie najwięcej skojarzeń $\mathrm{z}$ polityką wewnętrzną dotyczyło Władimira Putina (75\%), którego respondenci nie tylko wymieniali, ale dodatkowo określali, np.: despotyczne rzady jednego przywódcy; ciężka ręka prezydenta; silna władza. Polityka wewnętrzna była też charakteryzowana poprzez takie wyrazy (20\%), jak: niestabilna; nieukształtowana; korupcja.

f) Polityka zagraniczna (10,68\% wszystkich asocjacji dotyczących obszaru rosyjskiego)

Reakcje werbalne na bodziec 'rosyjska polityka zagraniczna' można podzielić na dwie grupy. Pierwsza (48\%), zdecydowanie negatywna, dotyczy takich zidentyfikowanych określeń, jak: agresywna; chęć zawtadnięcia światem; wojna w Czeczenii; konflikt z Ukraina; Smoleńsk; brak wspótpracy z innymi krajami, druga (24\%), stanowczo mniej liczna, zawiera opisy pozytywne, np. dobra wspótpraca $z$ Chinami; bardzo wysoki poziom; godna pochwały - pewność swojej pozycji w świecie i dbałość o utrzymanie tej pozycji.

\section{Druga część ankiety - obszar białoruski}

a) Białoruś (19,31\% wszystkich asocjacji dotyczących obszaru białoruskiego)

Białoruś w pierwszej kolejności kojarzy się studentom z sytuacją ekonomiczną tego kraju. Reakcje werbalne $(35,71 \%)$ koncentrowały się na takich sformułowaniach, jak bieda; mato zarabiaja; biedniejszy sasiad - ma gorzej niż my w Polsce. Druga grupa asocjacji (32,14\%) ukierunkowana była na określenia typu: kraj na wschód od Polski; sasiad; granica; przejście graniczne w Kuźnicy Białostockiej. Respondenci kojarzą Białoruś z dwoma miastami (21,43\%) - Mińskiem oraz Grodnem.

b) Białorusini (28,96\% wszystkich asocjacji dotyczących obszaru białoruskiego)

Asocjacje językowe związane $\mathrm{z}$ mieszkańcami Republiki Białorusi można zaszeregować do dwóch grup. Pierwsza $(47,62 \%)$ - koncentruje się na 
pozytywnych cechach charakteru, osobowości Białorusinów, np.: gościnność; przyjaźni; otwartość; pracowici; mili). Druga grupa $(33,33 \%)$ zarejestrowanych słów, wyrażeń, a nawet zdań dotyczy postrzegania Białorusinów jako turystów przyjeżdżających do Polski $w$ celach zakupowych, handlowych oraz znalezienia pracy (zakupy w polskich supermarketach; przyjeżdzaja do Polski w poszukiwaniu pracy; przemyt do Polski alkoholu i papierosów).

c) Kultura białoruska (20\% wszystkich asocjacji dotyczących obszaru białoruskiego)

Największa liczba skojarzeń $(51,17 \%)$ w tym punkcie ankiety kreuje ludowy, tradycyjny obraz kultury białoruskiej. Na obraz ten składają się, np.: białoruski ornament; stroje narodowe; folklor; naszywki na ubraniach, ale też, incydentalnie, Iwan Mieleż. Studenci w swoich odpowiedziach (13,79\%) zwracali też uwagę na to, iż język i kultura białoruska są zagrożone wymarciem na rzecz języka rosyjskiego (zanika ich język ojczysty; coraz mniej ludzi postuguje sie językiem białoruskim;, jezyk białoruski jest na wymarciu, młodzi ludzie postuguja się niemal wytacznie rosyjskim). Respondenci $\mathrm{w}$ swoich reakcjach na bodziec 'kultura białoruska' akcentowali jej podobieństwo do kultury polskiej (13,79\%), pisząc m.in.: podobna do polskiej; bliska mojej, przyjazna mi.

d) Gospodarka (12,41\% wszystkich asocjacji dotyczących obszaru białoruskiego)

Zdecydowana większość reakcji językowych (72,22\%) odnoszących się do gospodarki naszego wschodniego sąsiada dotyczyła jej niskiego rozwoju (np. stabo rozwinięta; niestabilna; bieda; zacofana). Ankietowane osoby zwróciły też uwagę na rolnictwo $(16,66 \%)$ jako główny dział gospodarki zapewniający zaspokojenie potrzeb Białorusinów.

e) Polityka wewnętrzna ( $8,96 \%$ wszystkich asocjacji dotyczących obszaru białoruskiego)

Główne konotacje (53,85\%) na bodziec 'polityka wewnętrzna' związane są z określeniami, charakteryzującymi jej obecny stan, np.: średnia; ekonomiczny kryzys; uzależnienie od Rosji oraz z prezydentem A. Łukaszenko (38,46\%).

f) Polityka zagraniczna (10,34\% wszystkich asocjacji dotyczących obszaru białoruskiego)

Reakcje werbalne odnoszące się do polityki zagranicznej Białorusi wskazują na jej powiązanie głównie z Rosją (66,67\%), np.: Białoruś jest zupełnie uzależniona od Rosji; Putin $i$ Łukaszenka = bliska wspótpraca; handel z Rosją. Respondenci 
wskazywali również w tym punkcie ankiety (26,67\%) na słaby poziom polityki zagranicznej, jej nieporadność; wojny wewnętrzne.

\section{Trzecia część ankiety - obszar ukraiński}

a) Ukraina (21,02\% wszystkich asocjacji dotyczących obszaru ukraińskiego)

Największą grupę skojarzeń odnotowanych przy bodźcu 'Ukraina' stanowią reakcje werbalne odnoszące się do sytuacji społeczno-gospodarczej tego kraju $(29,73 \%)$. W tym punkcie ankiety respondenci pisali m.in.: bieda; mały, słabo rozwinięty kraj; kraj, w którym pensja przeciętnego człowieka jest dwa razy niższa niż potrzebuje na życie. Kolejna grupa $(24,32 \%)$ - to asocjacje oscylujące wokół konfliktu zbrojnego oraz wydarzeń politycznych na Ukrainie (wojny; wojna o Krym; pomarańczowa rewolucja). Studenci wymieniali również nazwy miejsc (Kijów; słoneczna Odessa, wejście do Morza Czarnego), które stanowiły 16,22\% reakcji językowych.

b) Ukraińcy (21,02\% wszystkich asocjacji dotyczących obszaru ukraińskiego)

Naród mieszkający w granicach Ukrainy, w pierwszej kolejności, kojarzy się z pozytywnymi cechami charakteru i osobowości (51,35\%). Polscy studenci określali Ukraińców między innymi jako ludzi pracowitych, otwartych, gościnnych, radosnych, miłych, życzliwych. Druga grupa konotacji (32,43\%) dotyczyła sytuacji ekonomicznej mieszkańców Ukrainy, a wśród nich odnotowano takie odpowiedzi, jak: tania siła robocza; brak perspektyw; szukaja pracy w Polsce; emigruja do innych krajów by żyć lepiej.

c) Kultura ukraińska (21,02\% wszystkich asocjacji dotyczących obszaru ukraińskiego)

Reakcje werbalne na bodziec kultura ukraińska można przyporządkować do dwóch głównych grup - kuchnia ukraińska (32,43\%) i ludowość $(37,84 \%)$. Na ludowy charakter kultury ukraińskiej składają się między innymi takie reakcje, jak: wyszywane koszule; stroje narodowe; folklor; warkocze u kobiet; malownicze wsie. Natomiast kuchnia ukraińska to m.in.: pierogi; barszcz ukraiński; cepeliny; okroszka; czeburek; kwas chlebowy; syrnik i inne.

d) Gospodarka (12,5\% wszystkich asocjacji dotyczących obszaru ukraińskiego)

Główne skojarzenia dotyczące gospodarki ukraińskiej wskazują na to, że polscy studenci postrzegają Ukrainę jako państwo biedne, którego gospodarka przeżywa trudności rozwojowe (np.: bieda; na bardzo niskim poziomie; czy ona w ogóle istnieje?, ubóstwo). 
e) Polityka wewnętrzna (14,77\% wszystkich asocjacji dotyczących obszaru ukraińskiego)

Reakcje językowe (42,31\%) ukazują ukraińską politykę wewnętrzną w negatywnym świetle. Sa to takie zapisy, jak: nieporadność; korupcja; problemy wewnętrzne; bałagan. Dwie kolejne grupy skojarzeń werbalnych odnoszą się do nowego prezydenta (23,08\%) oraz niespokojnej sytuacji w kraju (23,08\%). Studenci odnotowali m.in.: nowy prezydent Załenski; prezydentem został satyryk; prezydent aktor - komik oraz wojna domowa; euromajdan; walki; pomarańczowa rewolucja.

f) Polityka zagraniczna $(9,66 \%$ wszystkich asocjacji dotyczących obszaru ukraińskiego)

W tym punkcie ankiety studenci jednoznacznie wskazywali na stosunki Ukrainy z Rosją (47,06\%). Zarejestrowane zostały takie reakcje językowe, jak: konflikt z Rosja; wojna z Rosja; uzależniona od Rosji. Taka sama liczba reakcji werbalnych $(47,06 \%)$ dotyczy oceny polityki zagranicznej Ukrainy i jej charakterystyki. Tu studenci pisali m.in.: niemoc; brak pomocy; nieogarnięcie; emigracja zarobkowa Ukraińców na Zachód; brak zdecydowania co do sojuszu z UE.

\section{WNIOSKI}

Wyniki zebrane podczas badania w postaci 555 zapisanych przez studentów reakcji werbalnych na wskazane $\mathrm{w}$ ankiecie bodźce pozwalają odnieść się do postawionych pytań badawczych.

\section{1) Jaka jest wiedza studentów na temat społeczności, z którymi mogliby oni realizować swoje potrzeby zawodowe, porozumiewając się w języku rosyjskim?}

Analiza wyekscerpowanego materiału pozwoliła ustalić, jaka wiedza o poszczególnych kulturach dominuje w świadomości młodych ludzi. Biorąc pod uwagę kryterium ilościowe, analiza reakcji werbalnych na wskazane bodźce pokazała, że w ramach obszaru rosyjskiego studenci dysponują największą wiedzą o kulturze rosyjskiej, w obrębie obszaru białoruskiego - o Białorusinach oraz, w zakresie obszaru ukraińskiego - w jednakowym stopniu o Ukrainie, Ukraińcach i kulturze ukraińskiej. Najmniej reakcji językowych odnotowano na temat rosyjskiej i białoruskiej polityki wewnętrznej oraz na temat ukraińskiej polityki zagranicznej. Taki rozkład ilościowy poszczególnych sieci skojarzeniowych może nie dziwić, ponieważ studenci filologii rosyjskiej w ramach studiów najwięcej informacji zdobywają o kulturze rosyjskiej. Ponadto mają oni bardzo utrudniony kontakt z Rosjanami, a Rosja, ze względów na 
ograniczone możliwości wjazdu do tego kraju, nie jest dostępna bezpośredniej obserwacji i poznaniu. Białorusini i Ukraińcy wydają się być studentom znaną nacją ze względu na pobyty turystyczne, zarobkowe czy handlowe tych społeczności w Polsce. Podobnie jak Rosja, tak i Białoruś jest dla większości Polaków nieznana ze względu na brak możliwości, choć w przypadku Federacji Rosyjskiej bardziej ograniczona, swobodnego bezwizowego przekraczania granicy tego kraju. Ilościowe reakcje słowne oraz przeświadczenie o znajomości Białorusinów i Ukraińców wskazują że studenci mają złudne poczucie wiedzy tak o Białorusi i kulturze białoruskiej, jak i o Ukrainie i kulturze ukraińskiej.

Gospodarka, polityka wewnętrzna czy zagraniczna poszczególnych krajów nigdy nie cieszyła się dużym zainteresowaniem wśród młodych ludzi, co przekłada się na ich wiedzę $\mathrm{z}$ tego zakresu. W przypadku niniejszego badania, te trzy bodźce wobec Rosji stanowiły razem 32,48\% wszystkich reakcji dotyczących obszaru rosyjskiego, wobec Białorusi - 31,72\% wszystkich konotacji w obszarze białoruskim, wobec Ukrainy - 36,93\% wszystkich skojarzeń w obszarze ukraińskim. Biorąc pod uwagę dane ilościowe, wiedza o poszczególnych państwach statystycznie jest porównywalna. Warto jednak zauważyć, że wiedza o gospodarce rosyjskiej, polityce wewnętrznej i zagranicznej, jako część szeroko rozumianej kultury Rosji, powinna być znacząco większa w porównaniu do dwóch pozostałych krajów. Można jedynie wnioskować, że informacje na ten temat są marginalnie eksponowane w ramach różnych przedmiotów na filologii rosyjskiej, a wiedza studentów jest pozyskiwana ze środków masowego przekazu. Jeśli chodzi o wiedzę o gospodarce, polityce wewnętrznej i zagranicznej Ukrainy i Białorusi to odpowiedzi ankietowanych osób świadczą o tym, że najprawdopodobniej jest ona zdobywana jedynie z internetu, telewizji oraz opinii innych ludzi mniej lub bardziej interesujących się tymi obszarami.

Jakościowa analiza sieci skojarzeniowych pokazała, że w świadomości młodych ludzi - rusycystów, obraz Rosji to przede wszystkim monstrualny, ale piękny kraj, ubarwiony stereotypowymi rosyjskimi symbolami takimi, jak cerkwie, matrioszki, niedźwiedzie, bliny, na czele którego stoi Putin. Federacja Rosyjska kojarzy się również z typowymi miejscami. Są to Moskwa, Petersburg, Kreml, Plac Czerwony, Syberia (Sybir). Odpowiedzi w ankiecie rysują truistyczny obraz Rosjanina. Jest on gościnny i otwarty, dobrze i bogato ubrany, jednak nadużywa alkoholu. Rosyjska kultura wysoka -literatura, muzyka, architektura - oceniana jest przez studentów filologów jako wspaniała, piękna, bardzo bogata. Wymieniają oni ośmiu klasyków literatury rosyjskiej, najwybitniejszych twórców XIX i I poł. XX wieku oraz tytuł baletu skomponowanego przez Piotra Czajkowskiego. Respondenci kojarzą Rosję z powszechnie znaną piosenką Ałły Pugaczowej oraz, równie znanym publiczności polskiej, Chórem Aleksandrowa. Asocjacje związane z kulturą rosyjską oscylują również wokół typowych rosyjskich dań, sztuki ludowej, reprezentowanej przez matrioszkę i samowar, strojów narodowych, folkloru, a 
także religii prawosławnej. Takie skojarzenia nie zaskakuja dotyczą wiedzy powszechnie znanej i mogą być przywołane przez osoby, które nie są studentami filologii rosyjskiej. Gospodarka rosyjska oceniania jest wysoko, kojarzy się z szybkim rozwojem, opartym głównie na zasobach naturalnych, głównie na surowcach energetycznych. Zebrany materiał badawczy świadczy o tym, że polityka wewnętrzna i zagraniczna wywołuje najczęściej negatywne konotacje. Skojarzenia oscylują głównie wokół działań wojennych, w których uczestniczy Rosja, rzadziej - reakcje językowe mają charakter aprobujący politykę zagraniczną. Polityka wewnętrzna Rosji kojarzy się respondentom z jej prezydentem - Władimirem Putinem i jego surową władzą.

Powyższy obraz Rosji można określić jako sztampowy i znany z innych badań (Michalik, Michalska-Suchanek 2010, Gawarkiewicz 2012, Żebrowska 2014, Karolczuk 2016). Może on jednak nieco dziwić, ponieważ jest wykreowany przez respondentów, którzy pozyskują wiedzę nie tylko ze środków masowego przekazu, ale też ze źródła akademickiego. Obraz ten dowodzi, jak silnie zakorzenione są stereotypy narodowe, które trudno jest zastąpić lub uzupełnić inną wiedzą i poszerzyć horyzonty młodego człowieka, wchodzącego w dorosłe życie z określonym, uwierającym balastem, który być może wpłynie na jego sukcesy zawodowe. Oczywiście można częściowo usprawiedliwić ten portret, ponieważ jak już wspomniano wyżej, deficyt prawdziwego poznania obcej/innej kultury poprzez bezpośrednie $\mathrm{z}$ nią obcowanie rodzi powyższe konsekwencje. Na pewno wiedza dotycząca obszaru rosyjskiego jest znacząco większa w porównaniu do dwóch pozostałych kultur.

Na podstawie analizy wyników materiału badawczego można stwierdzić, że wiedza polskich studentów na temat Białorusi i Ukrainy, ich mieszkańców i kultury jest uboga. Białoruś i Ukraina postrzegane są głównie przez pryzmat złej sytuacji ekonomicznej w obu krajach. Pierwsze państwo dodatkowo kojarzone jest z oczywistym faktem bycia wschodnim sąsiadem Polski, drugie przede wszystkim z wojną i niestabilną sytuacją polityczną. Reakcje werbalne pokazują że respondenci kojarzą kilka powszechnie znanych miast i miejsc znajdujących się na terytorium tych państw. Studenci mają bardzo podobne konotacje odnośnie Białorusinów i Ukraińców; najczęściej widzą w naszych sąsiadach pozytywne cechy charakteru, zachowania, ale również osoby znajdujące się w złej sytuacji finansowej, zmuszone do opuszczenia swego kraju w celach zakupowych lub zarobkowych. Na obraz kultury tak białoruskiej, jak i ukraińskiej składają się głównie ludowe elementy. Kultura ukraińska wywołuje również konotacje związane z tradycyjnymi daniami serwowanymi na Ukrainie. Warto tu zauważyć, że większość z wymienianych potraw jest znana studentom jako tradycyjne potrawy kuchni rosyjskiej. Respondenci podkreślali, że kultura białoruska jest podobna do polskiej; są świadomi również tego, iż język białoruski jest zagrożony wymarciem, ponieważ obywatele Białorusi na co dzień posługują się językiem rosyjskim. Gospodarka 
obu omawianych państw kojarzona jest ze słabym jej rozwojem, a nawet bieda, zacofaniem czy ubóstwem. Podobnie postrzegana jest polityka wewnętrza obu krajów - pełna problemów, nieporadności, nieuczciwości. Dodatkowo odnotowane reakcje językowe pokazały, że studenci znają obecnych prezydentów Białorusi i Ukrainy, tj. Aleksandra Łukaszenkę i Wołodymyra Zełenskiego, wskazując jednocześnie, że jest on aktorem, komikiem, satyrykiem. Polityka zagraniczna Białorusi, podobnie jak i wewnętrzna, zdaniem studentów, oparta jest na ścisłej współpracy $\mathrm{z}$ Rosją a nawet uzależnieniu od Moskwy. Natomiast polityka zagraniczna Ukrainy również percypowana jest $\mathrm{w}$ kategoriach powiązania $\mathrm{z}$ Federacją Rosyjska, ale ukierunkowana na konotacje związane z wojną. Polityka zagraniczna Białorusi i Ukrainy kojarzona jest z niezaradnością bezsilnością emigracją zarobkową obywateli.

Opisany powyżej obraz Białorusi i Ukrainy wskazuje, że wiedza dotycząca politycznych i gospodarczych problemów nie jest nieprawdziwa, ale na pewno cechuje ją wybiórczość oparta głównie na informacjach medialnych. Wiedza o Białorusi i Ukrainie jako państwach oraz kulturze białoruskiej i ukraińskiej jest również bardzo uproszczona, sztampowa, znana ze środków masowego przekazu. Natomiast wydaje się, że respondenci nie posiadają wiedzy o miastach, miejscach, zabytkach, czy też o współczesnej kulturze popularnej i wysokiej naszych wschodnich sąsiadów. Ich bardzo powierzchowna znajomość współczesności ogranicza się wyłącznie do obszarów politycznych.

\section{2) Jakie asocjacje (pozytywne, negatywne, neutralne) na temat państw sąsiadujących z Polską dominują w świadomości młodych ludzi?}

Analiza sieci skojarzeń odnoszących się do trzech obszarów kulturowych pokazała, że można je przyporządkować do 3 grup: pozytywnych, negatywnych i neutralnych. Należy jednak zaznaczyć, że żadna grupa nie jest w pełni homogeniczna.

Zdecydowanie najwięcej asocjacji pozytywnych zaobserwowano przy takich bodźcach jak, Rosjanie (np.: gościnni; otwarci; pomocni), Białorusini (np.: gościnni; przyjaźni; otwarci) i Ukraińcy (np.: pracowici; otwarci; gościnni). Respondenci skupiali się głównie na pozytywnych cechach tych narodowości. Sporadycznie pojawiały się tu również skojarzenia o charakterze neutralnym i negatywnym. Ciekawe jest to, że studenci przypisują trzem narodowościom podobne cechy charakteru, co może sugerować, iż w oczach młodych ludzi są one do siebie podobne.

Konotacje dotyczące Rosji, kultury i gospodarki rosyjskiej, Białorusi, białoruskiej kultury i polityki wewnętrznej oraz kultury ukraińskiej można określić jako neutralne. Warto zaznaczyć, że nie odnotowano skojarzeń negatywnych przy wszystkich trzech bodźcach odnoszących się słowa 
'kultura'. Nieliczną grupę stanowią konotacje zdecydowanie pozytywne, wyrażające się w takich określeniach, jak: piękne stroje ludowe; piękny język; piękna architektura (kultura rosyjska), piękne zdobienia; dobre jedzenie (kultura białoruska), piękne miasto Lwów; malownicze wsie (kultura ukraińska). Pozostałe bodźce incydentalnie zawierają skojarzenia negatywne i pozytywne. I tak, Rosja to piękny kraj i troche wróg, gospodarka rosyjska szybko się rozwija i dotyka ją inflacja, Białoruś kojarzy się z pracowitym narodem i zacofaniem, natomiast polityka wewnętrzna Białorusi jest uzależniona od Rosji.

Skojarzenia negatywne oscylują wokół takich obszarów, jak polityka zagraniczna Rosji, Ukraina, białoruska polityka zagraniczna oraz gospodarka, polityka wewnętrzna i zagraniczna Ukrainy. W obrębie pięciu ostatnich bodźców nie zaobserwowano pozytywnych skojarzeń, zdecydowanie dominują negatywne (np.: polityka zagraniczna Białorusi - nieporadność; gospodarka Ukrainy - upadająca, polityka wewnętrzna - korupcja, zagraniczna nieogarnięcie), a incydentalnie pojawiają się konotacje neutralne. Rosyjska polityka zagraniczna w swoim obrazie wykreowanym przez studentów obok dominujących asocjacji negatywnych (np.: agresywna; wojny) posiada również neutralne i pozytywne.

Sieć skojarzeniowa dotycząca gospodarki Białorusi i rosyjskiej polityki wewnętrznej zawiera tyle samo konotacji neutralnych (np.: gospodarka Białorusi - uprawa zbóż, polityka wewnętrzna Rosji - silna władza, państwo, przywódcy), jak i negatywnych (gospodarka Białorusi - źle zarządzana, polityka wewnętrzna Rosji - bezwzględność). Asocjacje pozytywne stanowią tu pojedyncze ilości.

Materiał badawczy pokazuje, że studenci w swoich ocenach 'inności' dzielą ją na trzy zakresy: człowiek - kultura - gospodarka i polityka. Pozytywnie nastawieni są do ludzi reprezentujących inne kultury, a antypatia nasila się w kierunku negatywnego postrzegania i oceny sytuacji gospodarczopolitycznej poszczególnych państw. Sympatia wyrażania w reakcjach językowych wobec naszych wschodnich sąsiadów może sprzyjać skutecznemu porozumiewaniu się szczególnie na płaszczyźnie towarzyskiej, ale też niekiedy zawodowej. Natomiast negatywna ocena gospodarki i polityki poszczególnych krajów, niedostrzeganie szans rynkowych może hamować przedsiębiorczość młodych ludzi i ograniczać ich inicjatywę w kreowaniu miejsca pracy, w którym mogliby wykorzystać nabytą podczas studiów wiedzę i umiejętności.

\section{3) Czy studenci filologii rosyjskiej są przygotowani do porozumiewania się interkulturowego z przedstawicielami innych kultur?}

Wyniki przeanalizowanego materiału badawczego pokazuja że nie można powiedzieć, iż studenci filologii rosyjskiej nie są przygotowani do porozumiewania się interkulturowego, ale też ich gotowość do efektywnej 
komunikacji nie jest wystarczająca. Świadczą o tym tak ilościowe, jak i jakościowe wyniki badania.

Wiedza na temat innych (obcych) kultur pozyskana w procesie bezpośredniego obcowania $\mathrm{z}$ jej wytworami oraz przedstawicielami jest najlepszym sposobem na kształtowanie kompetencji interkulturowej $i$ przygotowanie się do efektywnego porozumiewania się. Jak pokazuje niniejsze badanie, studenci posiadają kontakt (ale raczej powierzchowny) z osobami rosyjskojęzycznymi w Polsce, głównie - z Białorusinami ( $g d y$ przyjeżdżaja do Polski na zakupy to zachowuja sie bardzo gburowato, mieszkajac na state w PL sa ok) i Ukraińcami (dużo Ukraińców pracuje w Polsce). Prawdopodobnie najczęściej są to jedynie obserwacje zachowań obcokrajowców w sklepach, relacje z kolegami, którzy studiują filologię rosyjską lub kontakty pojedynczych polskich studentów $\quad \mathrm{z}$ studentami rosyjskojęzycznymi w czasie wymian międzynarodowych w ramach programu Erasmus+. Należy jednak zaznaczyć, że liczba obcokrajowców, dla których język rosyjski jest językiem pierwszym lub drugim, ale nie obcym, na każdym roczniku jest niewielka. Obserwacje autora niniejszej publikacji pokazują również, że rzadko dochodzi do koleżeńskich kontaktów między polskimi i zagranicznymi studentami, które sprzyjają lepszemu poznaniu innej kultury i praktyce języka rosyjskiego. Natomiast w wymianach międzynarodowych w ramach programu Erasmus+ bierze udział bardzo mała liczba studentów na kierunku filologia rosyjska (około 4 osoby rocznie), którzy wyjeżdżają do państw Unii Europejskiej - nie do Rosji, na Ukrainę czy Białoruś. Sporadycznie, na mocy zawartych międzynarodowych umów, dochodzi do krótkoterminowych międzynarodowych wymian studentów polskich i białoruskich lub semestralnych, w których uczestniczy niewielka ich liczba (3 osoby z Polski i 3 z Białorusi). Incydentalnie dochodzi też do prywatnych kontaktów z osobami rosyjskojęzycznymi (np. pojedyncze skojarzenia $\mathrm{z}$ Rosjanami - moja ukochana przyjaciółka z Kaługi, z Białorusinami interesująca znajoma z Mińska). Ten niewielki bezpośredni kontakt młodych Polaków z obcą kulturą odzwierciedla się w ankietach, w których dominuje stereotypowy, niekiedy płytki, obraz zaczerpnięty $\mathrm{z}$ środków masowego przekazu lub od znajomych. Natomiast osobiste wnikliwe poznanie inności zwykle wywołuje dużo głębsze skojarzenia, związane $\mathrm{z}$ prawdziwymi przeżyciami i doświadczeniami jednostki, których, wydaje się, zabrakło w zebranym materiale. Brak kontaktu z inną kultura, czyli jej prawdziwego poznania, wiedza wykształcona na bazie płytkich informacji, negatywne postawy wobec inności mogą hamować chęć wchodzenia w interakcje tak osobiste, jak i zawodowe oraz zniechęcać do podejmowania inicjatywy i kreowania swojej pozycji na rynku pracy.

Należy podkreślić, że duże znaczenie dla efektywnego porozumiewania się z przedstawicielami innej kultury ma edukacja szkolna i akademicka; może ona być znakomitym uzupełnieniem bezpośredniego poznania, ale 
niewystarczającym do rozwijania kompetencji interkulturowej, a w konsekwencji do efektywnego porozumiewania się z przedstawicielami obcej kultury. Dużo większa liczba skojarzeń z Rosją i Rosjanami niż z Białorusią i Białorusinami oraz Ukrainą i Ukraińcami może świadczyć o tym, że respondenci dysponują większą wiedzą na temat szeroko rozumianej kultury rosyjskiej, która jest pozyskiwana nie tylko ze środków masowego przekazu, ale również podczas formalnej edukacji akademickiej. Ponadto więcej skojarzeń pozytywnych dotyczących Federacji Rosyjskiej i jej obywateli, w porównaniu do dwóch pozostałych obszarów kulturowych, również może potwierdzać tezę o istocie rzetelnej wiedzy w przygotowaniu się do kontaktów z innymi kulturami.

Warto na koniec podkreślić, że niewątpliwie duże znaczenie dla efektywnych kontaktów interkulturowych mają pozytywne postawy studentów wobec ludzi reprezentujących obce kultury co odzwierciedla się w pozyskanej sieci skojarzeń. Najwięcej pozytywnych konotacji odnotowano przy takich bodźcach, jak: Rosjanie, Białorusini i Ukraińcy.

\section{PodsumowANIE}

Celem zaprezentowanego badania było pozyskanie od polskich studentów filologii rosyjskiej reakcji werbalnych na bodźce odnoszące się do kultury rosyjskiej, ukraińskiej i białoruskiej oraz ich analiza.

$\mathrm{Na}$ podstawie przeanalizowanego materiału można konstatować, że 'spontaniczna' wiedza studentów na temat Rosji, Ukrainy i Białorusi oraz Rosjan, Ukraińców i Białorusinów nie jest imponująca, a negatywne stereotypy nadal są zakorzenione w świadomości polskiego społeczeństwa. Warto jednak podkreślić, że asocjacje dotyczące Rosji i Rosjan wśród studentów filologii rosyjskiej są mniej sztampowe niż wobec dwóch pozostałych kultur. Proporcje te przekładają się również na wiedzę o poszczególnych kulturach. To właśnie określona wiedza, teoretyczna i pozyskana „namacalnie”, wpływa na postawy i umiejętności jednostki, a tym samym na kształtowanie kompetencji interkulturowej i efektywnego porozumiewania się z przedstawicielami innej kultury. W celu poprawy tej sytuacji oraz zwiększenia szansy studentów filologii rosyjskiej na rynku pracy warto uwspółcześnić cele uczenia się i kształcenia językowo-kulturowego na studiach wyższych $\mathrm{z}$ akcentem na uwrażliwienie interkulturowe. Należałoby umożliwić studentom jak najczęstszy bezpośredni kontakt $\mathrm{z}$ kulturą rosyjska; $\mathrm{W}$ programach akademickich warto zadbać o współczesną wiedzę na temat Rosji i Rosjan; wprowadzić elementy wiedzy na temat krajów, których obywatele mówią po rosyjsku oraz na temat społeczeństw sąsiadujących z Polska, które przyjeżdżają do naszego kraju w celach turystycznych, handlowych, zawodowych.

Warto stale pamiętać, że wiedza, postawy i umiejętności nie są konstruktem stałym. Mogą być modyfikowane poprzez doświadczenia 
życiowe, obserwacje otaczającego świata, weryfikowane w praktyce, poddawane refleksji i ocenie. Wszystkie czynniki powiązane są ze soba, implikują określone działania i kształtują kompetencje, a w konsekwencji przygotowują do właściwych kontaktów interkulturowych.

\section{BIBLIOGRAFIA}

ADEBAyO, C. T. Teaching perspective taking in intercultural context: Encounters with international teaching assistants with foreign accents [online]. London: Taylor \& Francise Online, 25/03/2019 [Dostęp: 03/08/2019]. Materiały dostępne na stronie: $<$ https://www.tandfonline.com/doi/full/10.1080/17404622.2019.1593473>.

APALKOW, W. G. : АПАЛЬКОВ, В. Г. Методика формирования межкультурной компетенции средствами әлектронно-почтовой групnь [online]. Moskwa: DocPlayer.ru, 2011 [Dostęp: 10/10/2016]. Materiały dostępne na stronie: $<$ https://docplayer.ru/342474-V-g-apalkov-metodika-formirovaniyamezhkulturnoy-kompetencii-sredstvami-elektronno-pochtovoy-gruppy.html>.

BIAŁEK, M. (2009), Kształcenie międzykulturowe w edukacji językowej, Wrocław, Oficyna Wydawnicza ATUT - Wrocławskie Wydawnictwo Oświatowe.

BIEBrICHTER, C.; EAST, M.; HOWARD, J.; TOLOSA, C. (2019), „Navigating intercultural language teaching in New Zealand classroom", Cambridge Joaurnal of Education, 49(5), 604-621.

BYRAM, M. (1997), Teaching and Assessing Intercultural Communicative Competence, Clevedon, Multilingual Matters.

GALSKOWA, N. D. : ГАЯЬСКОВА, Н. Д. (2008), „Образование в области иностранных языков: новые вызовы и приоритеты", Иностранные языки в школе, 5, 2-7.

GAWARKIEWICZ, R. (2012), Komunikacja międzykulturowa a stereotypy: Polacy - Niemcy Rosjanie, Szczecin, Uniwersytet Szczeciński.

GRABOWSKA, B.; KANIA, K. (2014), „Kompetencje międzykulturowe w świecie zróżnicowanego 'my'”, w Od wielokulturowości miejsca do międzykulturowości relacji społecznych, red. J. Nikitorowicz, J. Muszyńska, B. Boćwińska-Kiluk, Warszawa, Wydawnictwo Akademickie Żak, 162-176.

HyetT, N.; Lee, K. M.; KNEvel, R.; FortunAe, T.; YAU, M. K.; BORKOVIC, S. (2018), „Trialing Virtual Intercultural Learning With Australian and Hong Kong Allied Health Students to Improve Cultural Competency", Journal of Studies in International Educalion, 23(3), 389-406.

JelizAROWA, G. W. : ЕАИЗАРОВА, Г. В. (2005), Культура и обучение иностранным языкам, Санкт-Петербург, Каро.

KAROlCZUK, M. (2016), Nauczanie języka rosyjskiego jako drugiego języka obcego w Polsce z perspektywy edukacji międzykulturowej, Białystok, Wydawnictwo Prymat.

LippManN, W. (1997 [1922]), Public Opinion, New York, Free Press Paperbacks.

KORNACKA-SKWARA, E.; SKWARA, A. (2010), „Wybrane czynniki warunkujące jakość komunikacji międzykulturowej”, w Zrozumieć innego. Wspótczesne problemy komunikacji międzykulturowej, red. O. Glebova, M. Niemiec-Knaś, Częstochowa, Akademia im. Jana Długosza w Częstochowie, 111-127. 
LUBECKA, A. (2010), „Komunikacja międzykulturowa jako dialogiczne spotkanie z obcym", w Słowo w dialogu międzykulturowym, red. W. Chłopicki, M. Jodłowiec, Kraków, Krakowskie Towarzystwo „Tertium”, 25, 15-26.

MagAlA, S. J. (2011), Kompetencje międzykulturowe, Warszawa, Oficyna a Wolters Kluwer Business. (przeł. Dąbrowski, J. F., Cross-cultural Competence, London, Routledge, 2005).

Malau-Aduli, B. S.; Ross, S.; ADU, M. D. (2019), „Perceptions of intercultural competence and institutional intercultural inclusiveness among first year medical students: A 4-year study", BMC Medical Education, 19(1), 346. Materiały dostępne na stronie: <https://bmcmededuc.biomedcentral.com/articles/10.1186/s12909-019$1780-y>$.

MiHUŁKA, K. (2012), Rozwój kompetencji interkulturowej w warunkach szkolnych - mity a polska rzeczywistość (na przykładzie języka niemieckiego jako L3), Rzeszów, Wydawnictwo Uniwersytetu Rzeszowskiego.

MinUŁKA, K. (2015), „Postawy w procesie nabywania języka obcego”, Studia Niemcoznawcze, 56, 397-412.

MiLLER, J. M. (2000), „,Language Use, Identity, and Social Interaction: Migrant Students in Australia", Research on Language and Social Interaction, 33(1), 69-100.

MichALIK, U.; Michalska-Suchanek, M. (2010), „Wizerunek Rosji oraz Rosjan w świadomości Polaków", w Zrozumieć innego. Wspótczesne problemy komunikacji międzykulturowe, red. O. Glebova, M. Niemiec-Knaś, Częstochowa, Akademia im. Jana Długosza w Częstochowie, 159-175.

MYCZKO, K. (2002), „Kognition und interkulturelle Kompetenz”, w European Year of Languages 2001, red. T. Siek-Piskozub, Poznań, Wydawnictwo Naukowe UAM, 69-74.

PfEIFFER, W. (2001), Nauka języków obcych. Od praktyki do praktyki, Poznań, Wagros.

SADOCHIN, A. W. : Садохин, А. П., (2007), „Межкультурная компетентность: понятие, структура, пути формирования", Журнал соцчиологии и социильной антропологии, 10(1), 125-139. Materiały dostępne na stronie: $<$ http://www.old.jourssa.ru/2007/1/6aSadohin.pdf $>$.

SHADIEV, R.; SUN, A.; HUANG, Y.-M. (2019), „A study of the facilitation of cross-cultural understanding and intercultural sensitivity using speech-enabled language translation technology", Briyish Journal of Education Technology, 50(3), 1415-1433.

SUZUKI, M.; ANDO, N.; NISHIKAWA, H. (2019), „Recruitment of local human resources and its effect on foreign subsidiaries in Japan", Management Research Review, 42(8), 1014-1032.

TaKhTAROVA, S. S.; Abuzyarova, D. L.; KuZMinA, O. D. (2019), „Communication between Population of Germany and German-Speaking Switzerland: Intra- or Intercultural Communication?", Academic Journal of Interdisciplinary Studies, 8(2), 126-130.

WILCZYŃSKA, W. (2002), „Badania interkulturowe w praktyce dydaktycznej”, w European Year of Languages 2001, red. T. Siek-Piskozub, Poznań, Wydawnictwo Naukowe UAM, 127-137.

WILCZYŃSKA, W. (2005), „Czego potrzeba w udanej komunikacji interkulturowej?”, w Dydaktyka języków obcych a kompetencja kulturowa i komunikacja interkulturowa, red. M. Mackiewicz, Poznań, Wydawnictwo Wyższej Szkoły Bankowej, 15-26. 
ZHANG, X.; ZHOU, M. (2019), „Interventions to promote learners' intercultural competence: a meta-analysis", International Journal of Intercultural Relations, 71, 3147.

ŻEBROWSKA, А. : ЖЕБРОВСКА, А. (2014), „О межкультурной осведомленности студентов-русистов (на материале эмпирических данных)", Studia Rossica Posnaniensia, 39, 393-399. 